\title{
The Factors Influencing and Various Technological and Socio- Economic Constraints for Crop Diversification in Haryana
}

\author{
Harshit Bansal ${ }^{1}$, Shirish Sharma ${ }^{2}$, Raj Kumar ${ }^{1 *}$ and Ajay Singh ${ }^{1}$ \\ ${ }^{1}$ Department of Agricultural Economics, CCSHAU, Hisar, Haryana, India \\ ${ }^{2}$ Department of Agricultural Economics, SKRAU, Bikaner, Rajasthan, India \\ *Corresponding author: rajkumarkashyap301@gmail.com (ORCID ID: 000-0003-3089-6234)
}

Received: $14-04-2020$

Revised: $23-07-2020$

Accepted: 25-08-2020

\begin{abstract}
The study was undertaken in Rewari and Sonepat district of Haryana to analyze factors influencing and various technological and socio-economic constraints to crop diversification. The study was based on both primary and secondary data. The primary data was collected from randomly selected 25 farmers each from randomly selected villages. The secondary source of data used pertains to the period 2006-07 to 2016-17. To determine the factors influencing crop diversification multiple linear regression model was used as its superiority over the other regression models and is easy to compute and interpret. Among the factors influencing crop diversification, age, education and size of land holding signicantly affected crop diversification in a positive manner while, income affected in a negative manner. To determine the technological and socio-economic constraints to crop diversification Garret's ranking technique was used. Among the various technological and socio-economic constraints for crop diversification, lack of proper marketing facilities and lack of technical know-how were recorded to be the major constraints for crop diversification faced by farmers.

\section{Highlights}

( Among the various technological and socio-economic constraints for crop diversification, lack of proper marketing facilities and lack of technical know-how were recorded to be the major constraints for crop diversification faced by farmers.
\end{abstract}

Keywords: Diversification, constraints, factors influencing, Garret ranking

Diversification is an important part of the changing economy. Conceptually the term "diversification" has been derived from the word "diverge" which means to move or extend in the direction different from a common point (Jha et al. 2009). In Agriculture, diversification can be defined as shift from the regional dominance of one crop (like rice) to another crops (like oilseeds), or from one enterprise (like crop based) to another enterprise (like livestock) or to engage in other complimentary activities (Vyas, 1996). Agricultural diversification from the theoretical point of view may be considered as diversification of resources from low income generating crops to high income generating crops. In developing countries like India starts with a gradual shift towards diversification.

In the context of Indian agriculture, diversification has occurred both across and within crops, from one enterprises to another, an addition of complementary enterprise to main enterprises in the form of increasing income by increased and diverse use of resources and finally producing increased variety of commodities. Diversification is also viewed as uncertain precaution so as to reduce unemployment and variability in income,

\footnotetext{
How to cite this article: Bansal, H., Sharma, S., Kumar, R. and Singh, A (2020). The Factors Influencing and Various Technological and SocioEconomic Constraints for Crop Diversification in Haryana. Economic Affairs, 65(3): 409-413.
}

Source of Support: None; Conflict of Interest: None 
preventing farm income from falling below some minimum level such as customary family living plus repayment of loans etc. Farm diversification is also practised for profit maximization through reaping gains of complementary relationship. Under the situation of weather and market induced risk and capital constraints, diversification in agriculture are adopted as a strategy for stabilising farm incomes. The risk and uncertainty are measured by magnitude of farm output fluctuations suggesting change in farm plans with regard to prices, techniques and yields. Selection of products with low variability and stable production is also attempted for warding off unfavourable outcomes through diversification. Crop diversification referring to larger crop mix creates a land use competition among various crops and crop groups like food grains and non-food grains, especially on the small farms.

Crop diversification emanates from the opportunities it offers to reduce production and price risks, increasing yields, natural resource sustainability ecological balance, increasing flexibility, and sustain productivity and growth. Not only this, it creates opportunities for more labour absorption and higher incomes through more efficient use of resources and exploitation of comparative advantage. On a whole, crop diversification is a process, which on the one hand helps the growers to improve their per capital income and diffuse risk and on the other hand provides more diversified food items to consumers. It minimizes the risk associated with production of single crop and helps the farmers to liberate from poverty trap.

It also provides employments and prevents excessive migration and helps in earning foreign exchange. Several studies and experiences around the world prove that crop diversification promotes sustainable economic growth of a country. Traditional crop cultivation is subject to high degree of risk and uncertainty and provides only seasonal, irregular and uncertain income to the farmer. So, it is difficult for the farmer with meagre resources to sustain himself and his family and also to make investment in his farm. The diversification of agriculture towards selective high value crops like fruits and off-season vegetables, compatible with the comparative advantage of the region, is suggested as a viable solution to stabilize and raise farm income, increase employment opportunities and conserve and enhance the natural resources, principally land and water (Vyas, 1996).

\section{MATERIALS AND METHODS}

The sample for the field survey was drawn by adopting multistage sampling procedure for selecting state, districts, tehsil and villages. The Haryana state was purposively selected due to its proximity to metro politian cities like Delhi and Gurugram. The study was conducted in Rewari and Sonipat district of Haryana. Among all the districts of Haryana, two districts i.e. Rewari and Sonepat were selected based on lowest and highest area under high value crops (fruits and vegetables) respectively as shown in table 1. Further, Bawal tehsil from Rewari district and Rai tehsil from Sonepat district were randomly selected for the study.

Table 1: District-wise area and production under high value crops and other crops in Haryana, 2013-14 to $2016-17$

\begin{tabular}{lllll}
\hline & \multicolumn{2}{c}{ High value crops $^{1}$} & \multicolumn{2}{c}{ Other crops $^{2}$} \\
\cline { 2 - 5 } Districts & $\begin{array}{l}\text { Area (in } \\
\text { 000 ha) }\end{array}$ & $\begin{array}{l}\text { Production } \\
\text { (in 000 } \\
\text { tonnes) }\end{array}$ & $\begin{array}{l}\text { (in 000 } \\
\text { ha) }\end{array}$ & $\begin{array}{l}\text { Production } \\
\text { (in 000 } \\
\text { tonnes) }\end{array}$ \\
\hline Ambala & 29.65 & 391.56 & 168.59 & 756.23 \\
Panchkula & 11.47 & 200.34 & 35.63 & 112.36 \\
Yamunanagar & 42.61 & 664 & 189.96 & 6790.62 \\
Kurukshetra & 25.54 & 448.56 & 254.35 & 1068.4 \\
Kaithal & 7.62 & 117.1 & 352.05 & 1400.3 \\
Karnal & 39.7 & 602.11 & 356.42 & 1452.83 \\
Panipat & 36.5 & 474.36 & 156.75 & 598.9 \\
Sonipat & 46.92 & 714.76 & 271.92 & 958.36 \\
Rohtak & 18.1 & 238.25 & 217.25 & 624.94 \\
Jhajjar & 12.01 & 171.06 & 225.03 & 673.77 \\
Faridabad & 12.54 & 197.11 & 46.38 & 149.26 \\
Palwal & 10.47 & 150.77 & 159.06 & 527.56 \\
Gurugram & 29.13 & 369.42 & 100.42 & 295.73 \\
Nuh & 33.3 & 525.67 & 145.19 & 414.87 \\
Rewari & 6.38 & 83.68 & 181.46 & 476.66 \\
Bhiwani & 12.25 & 144.65 & 566.62 & 1358.3 \\
Jind & 15.58 & 221.24 & 436.01 & 1529.9 \\
Hisar & 15.13 & 220.14 & 536.45 & 1647 \\
Fatehabad & 17.71 & 218.27 & 386.02 & 1604.4 \\
Sirsa & 22.01 & 347.1 & 616.22 & 2436.3 \\
\hline SOurce: & & & & \\
\hline
\end{tabular}

Source: Statistical Abstract of Haryana 2013-14 to 2016-17; HVCs includes fruits and vegetables; Other crops includes cereals, pulses, oilseeds, cotton and sugarcane.

\section{Selection of Village}

A complete list of all the villages in the selected 
tehsil was prepared and two villages were selected randomly from each of the selected tehsil. Thus, four villages were selected at random from both the district (i.e. Rewari and Sonepat). The procedure resulted in selection of village Jabua and Khijuri from tehsil Bawal in Rewari district and village Aterna and Manoli from tehsil Rai in Sonepat district.

\section{Selection of Farmer}

A complete list of all cultivating households were prepared for the sample villages, using the information provided by concerned village Patwari and a sample of 25 cultivating households were selected randomly from each of the selected villages. Therefore, total sample size for the study was 100 farmers.

\section{Data Collection}

The primary data in order to address the objectives of the study was obtained from the selected farmers using a pretested well-structured schedule developed for the study through personal interview. Hence, field survey was conducted for the crop year 2018-19. The secondary data regarding area, production and productivity of different crops in Haryana was collected from different published sources like Department of Agriculture and Cooperation Network (DACNET), Indiastat, statistical abstract of Haryana, Agricultural Statistics at Glance and Horticulture at Glance etc for the period 200607 to 2016-17.

\section{Multiple Linear Regression}

To determine the factors influencing crop diversification multiple linear regression model was used as its superiority over the other regression models and is easy to compute and interpret. Multiple linear regression model is given by the following equation:

$$
Y=a_{0}+a_{1} X_{1}+a_{2} X_{2}+\ldots \ldots \ldots+a_{n} X_{n}+u
$$

Where,

$Y=$ SID value; $a_{0}=$ constant term; $X_{1}=$ size of land holding; $X_{2}=$ age; $X_{3}=$ income; $X_{4}=$ training facilities availed; $X_{5}=$ education level; $X_{6}=$ environmental factors; $X_{7}=$ incidence of pest and diseases.
The independent variables like size of land holding, education level, age, income, environmental factors, incidence of pest and diseases and training facilities availed were regressed with the crop diversification index i.e. SID value.

\section{Garret Ranking}

Various technological and socio-economic constraints to diversification were listed based on review of literature and the constraints were framed in questionnaire. Therefore, twelve factors were identified as the major reasons contributing to constraints for crop diversification in the study area taking into consideration the opinions of the sample farmers and with regard to the various studies undertaken in the field of study. Each of the sample farmer were asked to rank the factors from rank one to rank twelve. In this analysis, rank one meant most important factor and rank twelve meant least important factor. In the next stage, rank assigned to each factor by each individual was converted into per cent position using the following formula,

$$
\text { Percent position }=\frac{100\left(R_{i j}-0.50\right)}{N_{j}}
$$

where,

$$
\begin{aligned}
& R_{i j}=\text { Rank given for the } i^{\text {th }} \text { item }(1,2,3, \ldots \ldots . .12) \text { by } \\
& \text { the } j^{\text {th }} \text { individual } \\
& N_{j}=\text { Number of items ranked by the } j^{\text {th }} \text { individual } \\
& (1.2,3, \ldots \ldots \ldots, 100)
\end{aligned}
$$

Once the per cent positions were found, the per cent position of each rank was converted to scores by referring to table given in Garret and Woods worth (1969). Then the scores for each factor were summed over the number of sample farmers who ranked that factor. In this way, total scores were arrived at for each of the twelve reasons and mean scores were calculated by dividing the total score by the number of respondents, who gave ranks. Finally, overall ranking of the twelve reasons was done by assigning rank $1,2,3, \ldots . .12$ in the descending order of the mean scores.

\section{RESULTS AND DISCUSSION}

Multiple linear regression analysis was carried out to find out the factors influencing the crop diversification. Before running regression analysis 
all the independent variables (predictor variables) were subjected to specific statistic test to ensure non violation of assumption of regression analysis. The results are presented in Table 2. The Adjusted Co-efficient of multiple determination $\left(\overline{\mathrm{R}}^{2}\right)$ was 0.33 indicating that the variables included in the regression model explained about 33 per cent of the variation in crop diversification. Regression coefficients represent the mean change in the response variable for one unit of change in the predictor variable while holding other predictors in the model constant. The regression coefficient for age was 0.008 and for education was 0.36 which was statistically significant at 1 per cent while, for income and size of land holding regression coefficient were -0.023 and 0.041 respectively which were statistically significant at five per cent. This further explains that with the increase in training facility attended by farmers the risk to diversify their crop also reduces which was statistically insignificant in Haryana. Also, it can be concluded that farmers having higher income and large land holding size are more indulged in taking risk of diversifying towards high value crops.

Table 2: Factors influencing the crop diversification in Haryana

\begin{tabular}{|c|c|c|c|c|}
\hline $\begin{array}{l}\text { Sl. } \\
\text { No. }\end{array}$ & Variables & Parameters & b-value & t-value \\
\hline 1 & Constant & a & 0.149 & 1.36 \\
\hline 2 & Age $\left(X_{1}\right)$ & $\mathrm{B}_{1}$ & $0.008^{* *}$ & 5.70 \\
\hline 3 & Education $\left(\mathrm{X}_{2}\right)$ & $\mathrm{B}_{2}$ & $0.36^{* *}$ & 2.82 \\
\hline 4 & Income $\left(X_{3}\right)$ & $\mathrm{B}_{3}$ & $-0.023^{*}$ & -1.99 \\
\hline 5 & $\begin{array}{l}\text { Size of land holding } \\
\left(\mathrm{X}_{4}\right)\end{array}$ & $\mathrm{B}_{4}$ & $0.041^{*}$ & 2.04 \\
\hline 6 & $\begin{array}{l}\text { Training facility } \\
\text { availed }\left(X_{5}\right)\end{array}$ & $\mathrm{B}_{5}$ & -0.008 & -0.58 \\
\hline 7 & $\begin{array}{l}\text { Environmental } \\
\text { factors }\left(X_{6}\right)\end{array}$ & $\mathrm{B}_{6}$ & -0.039 & -0.77 \\
\hline 8 & $\begin{array}{l}\text { Incidence of pest and } \\
\text { disease }\left(X_{7}\right)\end{array}$ & $\mathrm{B}_{7}$ & -0.012 & -0.32 \\
\hline 9 & $\begin{array}{l}\text { Adjusted coefficient } \\
\text { of multiple } \\
\text { determination }\left(\overline{\mathrm{R}}^{2}\right)\end{array}$ & & & 0.33 \\
\hline
\end{tabular}

Note: 1 . ${ }^{* *}$-Significant at 1 per cent.; $2 .{ }^{*}$-Significant at 5 per cent.

Table 3 denotes, overall rank order of the constraints experienced in Haryana by farmers in crop diversification in the descending order of importance. At farm level, the major constraints in crop diversification in Haryana were captured using Garret ranking technique. Lack of proper marketing facilities was regarded as the major constraint to crop diversification as famers found it difficult to sell their produce in nearby market and had to go far which added more cost and reduced their share of return. Lack of technical know-how was regarded as the second most important constraint as most of the farmer didn't attended any training regarding crop diversification which made farmers difficult to diversify towards other crops and were reliable on knowledge from other farmers. It has been observed that respondent in Haryana found it difficult to have access to certified seeds in time as they did not have access to shops in village which could provide certified seeds and had to go far away due to which high cost and non-availabilty of certified seed in time was considered to be the third most important constraint. It has been seen that in some villages of Haryana there is still lack of irrigation facilities as the water table have been depleting over the years due to which farmers had to move to crops with less water requirement. Like in district Rewari the lack of irrigation facility was major constraint for the farmers which made them diversify their crops.

Table 3: Constraints for crop diversification in Haryana

\begin{tabular}{|c|c|c|c|}
\hline Sl. No. & . Constraints & Score & Rank \\
\hline 1 & Lack of proper marketing facilities & 77.16 & 1 \\
\hline 2 & Lack of technical know-how & 61.36 & 2 \\
\hline 3 & $\begin{array}{l}\text { High cost and non-availability of } \\
\text { certified seed in time }\end{array}$ & 61.08 & 3 \\
\hline 4 & $\begin{array}{l}\text { Lack of training and field } \\
\text { demonstration etc }\end{array}$ & 57.29 & 4 \\
\hline 5 & Lack of access of irrigation facilities & 53.93 & 5 \\
\hline 6 & $\begin{array}{l}\text { Low and imbalance rate of } \\
\text { fertilizer consumption }\end{array}$ & 52.76 & 6 \\
\hline 7 & $\begin{array}{l}\text { Vagaries of climate cause damage } \\
\text { to crops }\end{array}$ & 47.31 & 7 \\
\hline 8 & $\begin{array}{l}\text { Non-adoption of proper cropping } \\
\text { pattern }\end{array}$ & 46.75 & 8 \\
\hline 9 & Lack of soil testing facility & 44.17 & 9 \\
\hline 10. & Risk factor & 44.11 & 10 \\
\hline 11. & Illiteracy & 37.72 & 11 \\
\hline 12. & Lack of access of credit & 29.31 & 12 \\
\hline
\end{tabular}

The table 3 reveals that access to credit had not been major constraint to farmers for diversifying to other crops as either credit facility was easily 
available or farmers had their income from other sources like pension, private jobs or by indulging in enterprises other than agriculture. Further results from the table reveals that illiteracy was not major constraints to farmers but their lack of attending any training given by government institutions resulted in fear of profitable return from diversifying to other crops. Also, farmers instead of attending the training were more reliable on the knowledge of the other farmer who may or may not have attended any training due to which farmers in Haryana had lack of knowledge of fertilizer consumption and technical know-how due to which returns to their produce was less beneficial and farmers fear to diversify to other crops.

\section{CONCLUSION}

Agricultural growth and crop diversification is the major issue in agriculture in India. Haryana is one of the most agricultural advance state of India so it plays a major role in India's agriculture sector. Lots of changes take place in Haryana's agricultural sector due to economic reform. The study analyzes factors influencing and the various socio-economic and technological constraints which were responsible to affect the crop diversification. Among the factors influencing crop diversification, age, education and size of land holding signicantly affected crop diversification in a positive manner while, income affected in a negative manner. Among the various technological and socio-economic constraints for crop diversification, lack of proper marketing facilities and lack of technical know-how were recorded to be the major constraints for crop diversification faced by farmers.

\section{ACKNOWLEDGEMENTS}

Authors wish to acknowledge Swami Keshwa nand Rajasthan Agricultural University, Bikaner and all the farmers who participated in the study and made the study successful.

\section{REFERENCES}

Chinnadurai, M., Karunakaranb, K.R., Chandrasekaran, M., Balasubramanian, R. and Umanath, M. 2016. Examining linkage between dietary pattern and crop diversification: an evidence from Tamil Nadu. Agricultural Economics Research Review, 29: 149-160

Dembele, B., Bett, H.K., Kariuki, I.M., Bars, M.L. and Ouko, K.O. 2018. Factors influencing crop diversification strategies among smallholder farmers in cotton production zone in Mali. Advances in Agricultural Science, 6(3): 1-16

Garrett, H.E. and Woodworth, R.S. 1969. Statistics in psychology and education. Vakils, Feffer and Simons Pvt. Ltd. Bombay, pp. 329.

Girish, M. 2014. Constraints in diversification of rural economy. American International Journal of Research in Formal, Applied and Natural Sciences, 5(1): 54-64

Jamagani, Z.B. and Bivan, G.M. 2013. Factors influencing farmers diversification of their cropping enterprises: a case study of sabon gari local government area of Kaduna state, Nigeria. IOSR Journal of Agriculture and Veterinary Science, 3(4): 79-84.

Jha, B., Kumar, N. and Mohanty, B. 2009. Pattern of agricultural diversificationin India. Institute of Economic Growth, Delhi, working paper series E/302/2009.

Joshi, P.K., Gulati, A., Birthal, S. and Tewari, L. 2004. Agriculture diversificationin South Asia: patterns, determinants and policy implications. Economic and Political Weekly, 39(24): 2457-2467.

Kumar, S. and Gupta, S. 2015. Crop diversification toward high-value crops in India: a state level empirical analysis. Agricultural Economics Research Review, 28(2): 339-350.

Kumar, S. and Kumar, P. 2018. Agricultural diversification an opportunity for smallholders (A case study of Sonipat district of Haryana). IOSR Journal of Humanities and Social Science, 23(1): 55-63.

Mussema, R., Belay, K., Alemu, D. and Rashid, S. 2013. Factors affecting crop diversification: evidence from SNNPR, Ethiopia. International Journal of Agricultural Sciences. 3(6): 558-565.

Shahbaz, P., Boz, I. and Haq, S.U. 2017. Determinants of crop diversification in mixed cropping zone of Punjab, Pakistan. Direct Research Journal of Agriculture and Food Science, 5(11): 360-366.

Tirath, R., Badal, P.S., Singh, O.P. and Singh, R. 2015. Constraints to agricultural diversification in Mirzapur district of Uttar Pradesh. Economic Affairs, 60(2): 273-276.

Vyas, V.S. 1996. Diversification in agriculture: concept, rationale and approaches. Indian Journals of Agricultural Economics, 51(4): 636-643. 
